\title{
Intradural Disc Herniation - A Case Report
}

\author{
Intradural Disk Herniasyonu - Bir Olgu Sunumu
}

\author{
S K JAIN, I Vijay SUNDAR, Vinod SHARMA, Ravishankar S GOEL, Rajesh GUPTA \\ S.M.S Medical College and Hospital, Department of Neurosurgery, Jaipur, India
}

Corresponding Author: S K JAIN / E-mail: shashi_neelu@yahoo.com

\begin{abstract}
Intradural disc herniation is a rare entity that occurs most commonly in the lumbar spine particularly at L4-L5 region. Most often it is diagnosed intraoperatively in a case of simple intervertebral disc herniation. Contrast enhanced MRI is mandatory for pre operative diagnosis. We describe a case of a 40-year-old female who presented to us with pain lower back, pain in both lower limbs and urinary retention after a fall. She had previously been diagnosed as a case of prolapsed intervertebral disc disease and was being managed conservatively. An unenhanced MRI revealed a large disc herniation at L4-L5 level. L4 and L5 laminectomy was performed and a hard intradural mass was palpable. On opening the dura a fragment of intervertebral disc was found with a small rent in the anterior dura. The fragment was removed and the rent was sutured. The patient recovered well from the surgery. Intradural disc herniations must be considered in the differential diagnosis of prolapsed intervertebral disc disease especially with recent worsening of symptoms and mismatch of unenhanced MRI findings with intraoperative findings.
\end{abstract}

KEYWORDS: Intradural disc, Diagnosis, L4-L5 level, Lumbar disc

\section{öz}

İntradural disk herniasyonu en sık olarak lumbar omurgada ve özellikle L4-L5 bölgesinde oluşan nadir bir durumdur. Genellikle basit intervertebral disk herniasyonu durumunda intraoperatif olarak tanı konur. Kontrast maddeli MRG preoperatif tanı için şarttır. Bize bir düşmeden sonra bel ağrısı, her iki bacakta ağrı ve üriner retansiyonla gelen 40 yaşında bir kadın vakayı sunuyoruz. Daha önce prolapse intervertebral disk hastalığı tanısı konmuştu ve konservatif olarak takip ediliyordu. Kontrast maddesiz MRG L4-L5 seviyesinde büyük bir disk herniasyonu gösterdi. L4 ve L5 laminektomi yapıldı ve sert bir intradural kitle palpe edildi. Dura açıldığında anterior durada küçük bir yırtıkla birlikte küçük bir intervertebral disk parçası bulundu. Parça çıkarıldı ve yırtık dikildi. Hastanın durumu cerrahiden sonra düzeldi. İntradural disk herniasyonları prolapse intervertebral disk hastalığının ayırıcı tanısında özellikle belirtiler yakın zamanda kötüleşmişse ve kontrast maddesiz MRG bulguları intraoperatif bulgularla eşleşmiyorsa düşünülmelidir.

ANAHTAR SÖZCÜKLER: İntradural disk, Tanı, L4-L5 seviyesi, Lumber disk

\section{INTRODUCTION}

Lumbar intradural disc herniation was first described by Dandy in 1942 and comprises about 0.3\% of lumbar disc protrusions. It is uncommon but has been well described in a limited number of case reports. Intradural disc herniations [IDH] comprise $0.26-0.30 \%$ of all herniated discs. The preooperative diagnosis of IDH is still difficult, and requires contrast enhanced MRI of the spine. The importance of IDH lies in fact that most patients such patients are diagnosed as intervertebral disc disease and therefore the work up of these patients lacks contrast enhanced MRI. This leads to a situation where the finding of intradural disc comes as a surprise for the unprepared surgeon. Proper awareness of prevalence, symptoms, pathogenesis and appropriate investigations helps the surgeon reach a diagnosis pre operatively and hence be prepared.

\section{CASE REPORT}

A 40-year-old female presented to us with history of fall on stairs and pain lower back radiating to both lower limbs. She had developed urinary retention after the fall and had been catheterized at a local clinic. On examination the patient had severe pain lower back radiating to both lower limbs more so on the left side and SLR was 30 degrees in both lower limbs, and she also had bilateral weakness of foot dorsiflexion. An unenhanced MRI of the lumbar spine revealed large paracentral disc herniation with bilateral effacement of nerve roots at L4-L5 level. Intraoperatively L4 and L5 laminectomy was performed and patient was found to have bilateral severe compression of nerve roots at L4-L5 level more so on the left side. A hard intradural mass was palpable and decision was made to open the dura and explore the cord. On opening the dura a $1 * 2 \mathrm{~cm}$ fragment of intervertebral disc was seen in the spinal canal displacing the nerve roots peripherally. The fragment was excised and a small rent noted on the anterior dura that was sutured. Dura closed primarily and nerve root decompression ensured. Post operatively patient recovered smoothly and bladder sensations started developing after four days.

\section{DISCUSSION}

Intradural disc herniation [IDH] is a rare event and is frequently associated with symptoms worse than the regular lumbar 


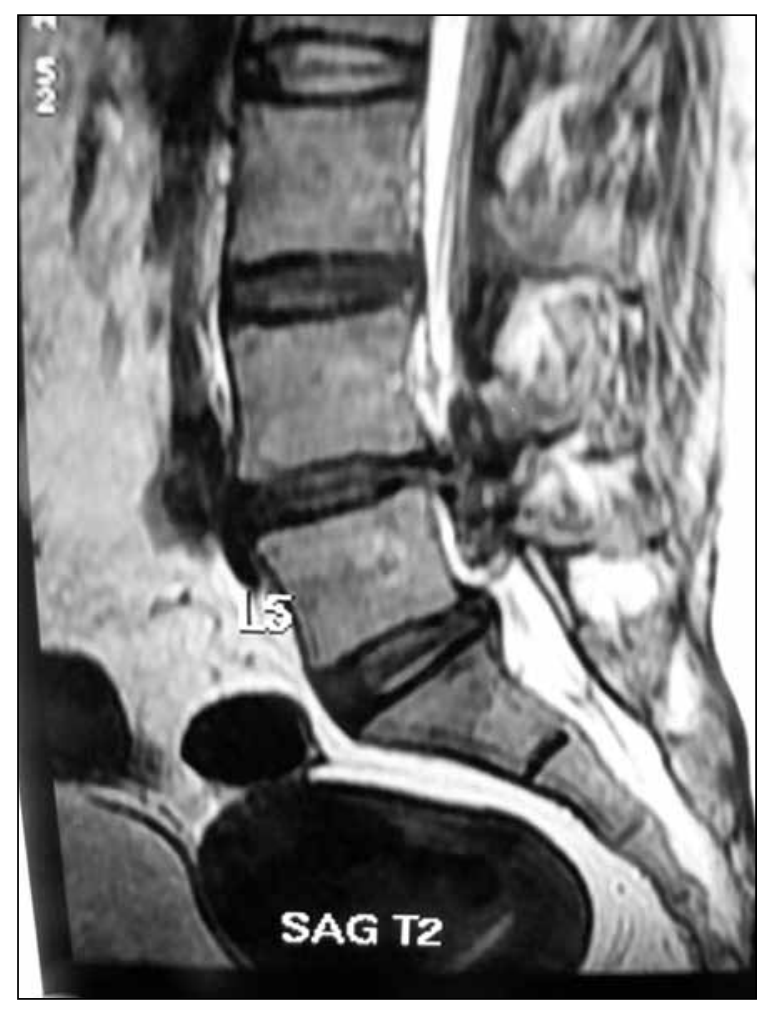

Figure 1: T2 sagittal MRI image showing disc herniation at L4-L5 level.

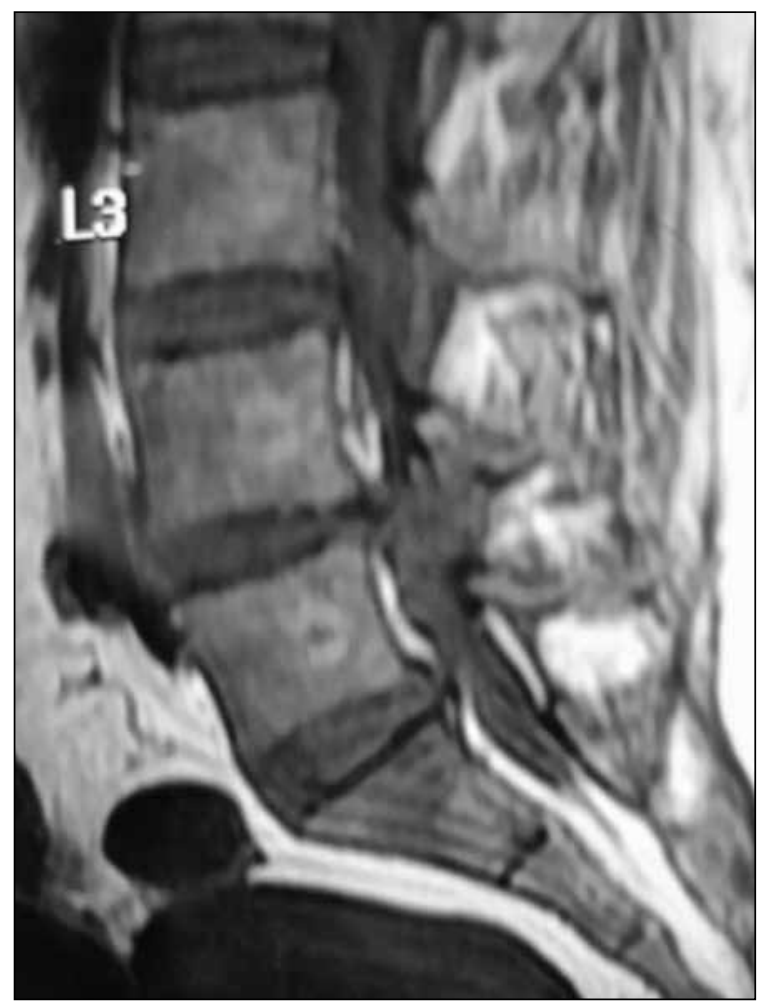

Figure 2: T1 sagittal MRI image showing disc herniation at L4-L5 level. disc herniation. Approximately 123 cases of IDH have been reported since 1942 (3). The majority of them occurred at the L4-L5 levels and only 12 cases occurred at L5-S1 In all, 5\% are found in the thoracic region, $3 \%$ in the cervical region and $92 \%$ in the lumbar region $(3,4)$. The site most frequently affected is L4-5 (55\%), followed by L3-4 (16\%) and L5-S1 (10\%) (1). Rarely,

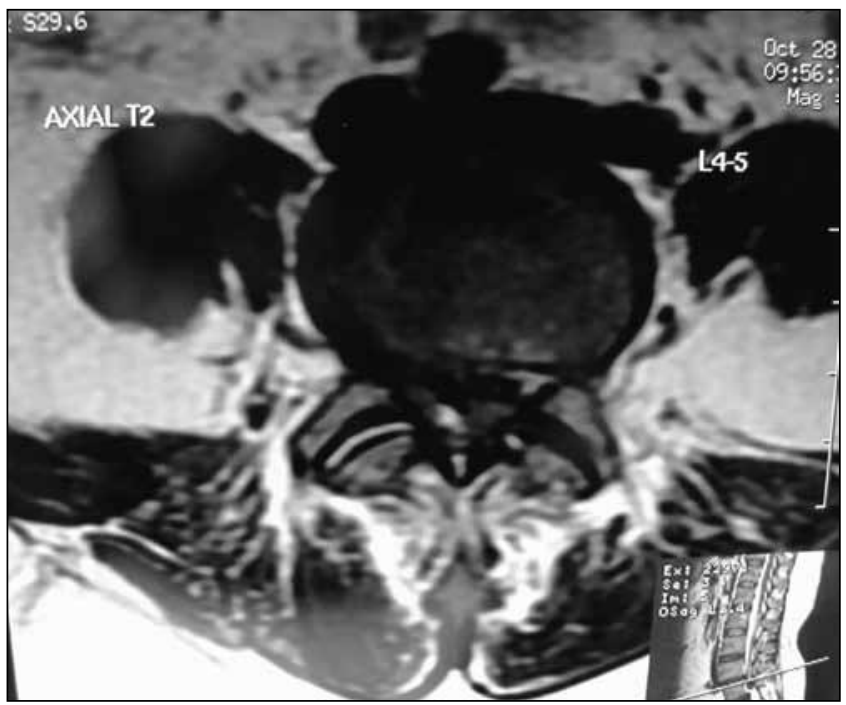

Figure 3: T2 axial MRI image at L4-L5 level showing intradural disc herniation.

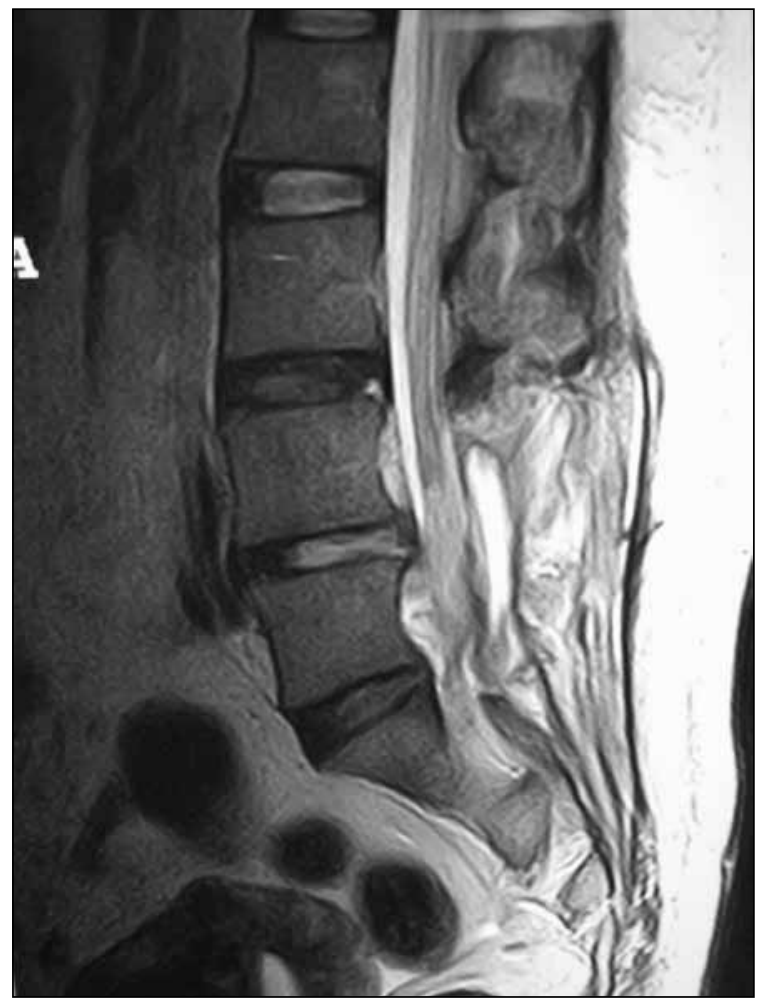

Figure 4: Post operative T2 Sagittal image of the patient. 
ruptured disc fragment may migrate intrathecally or may perforate the radicular sheath, leading to intraradicular disc $(13,10)$. The intraradicular type seems to be more frequently associated with previous surgery (14). Migration of the disc nucleus pulposus in the intradural site requires perforation of the annulus fibrosus, the posterior longtudinal ligament and the dura mater (6). The explanation of the dural perforation by the disc herniation is not clear though several reasons are known that may contribute like congenital narrowing of the spinal canal with less epidural space, adhesions between the annnulus fibrosus, posterior longitudinal ligament, duramater, ,congenital and iatrogenic fineness of the dura mater $(3,1,11)$. Blikra demonstrated presence of firm anatomic adhesions between the anterior wall of the dural sac and the posterior longitudinal ligament, particularly at the L4-L5 level (2). Thus in case of dural perforation, the herniated disc would perforate the annulus fibrosus, the PLL and the dura mater as if they were one structure. The existence of such an anatomic situation at has not been proven at other sites of lumbar disc levels. This can explain the anterior intradural herniation at L4-L5 but not the lateral or other levels.

Imaging of IDH requires contrast enhanced MRI (3). Unforunately this is not routinely advised in patients presenting with back pain and radiculopathy. Contrastenhanced MRI scans are essential both to diagnose and to differentiate a herniated disc from a disc space infection or tumor (5). The enhancement pattern of the intradural disc fragment is variable. Peripheral enhancement around the disc fragment is commonly seen on contrast MRI. A herniated disc fragment will rarely be enhanced centrally, which is attributed to vascular granulation tissue infiltrating the fragment (3). Some show intensely enhancing intradural disc fragment which might correlate with invasion of disc fragment with granulation tissue and reactive endothelial cells $(14,12)$. Intradural disc herniation is quite often a chronic pathology, and the disc enhances because of the chronic granulation tissue (3). Acute cases of IDH can pose problem because there is no granulation tissue hence no enhancement.

The MRI finding of an intradural lesion raises several diagnostic doubts that must be considered and resolved with differential diagnosis, which includes neurinoma, meningioma, ependymoma, and dermoid. Neurinoma and meningioma both have homogeneous enhancement and clearly different from the ring enhancement of intradural herniations. An important differential diagnosis is posterior epidural migration of herniated disc fragment which may also have a ring enhancing pattern on contrast enhanced MRI (9). In the myelographic examination, intradural disc herniations of the lumbar region usually show as a complete block.

The treatment of IDH basically involves surgical removal of ruptured disc material. At surgery, the dura and root must be carefully explored. IDH needs to be recognized and treated appropriately at the time of the initial operation to prevent the development of the back failure $(8,7)$. Cauda equina syndrome and sphincter disease have an incidence of $30 \%$ of all reported cases, as in our case (3). However, there may be cases where the disc protrudes intradurally to compress a single root and show single only of root compression. Intradural disc herniation above the conus medullaris seems to bring on neurologic dysfunctions more rapidly (8).

\section{CONCLUSION}

Intradural disc herniation is a rare variant of a very common disease that merits mention because of the need of awareness of its existence. The diagnosis is commonly an intraoperative surprise because contrast MRI is not routinely advised in evaluation of radicular pain. Intraradicular disc protrusion might result in failure of lumbar disc surgery. Therefore the intervertebral foramina and roots must be carefully explored in every case of lumbar disc herniation. Every neurosurgeon involved in spinal surgery must be aware of this rare pathology which, when overseen during the intervention, could have disastrous consequences for the patient.

\section{REFERENCES}

1. Aydin MV, Ozel S, Erdogan B, Yildirim T: Intradural disC mimicking: A spinal tumor lesion. Spinal Cord 42:52-54, 2004

2. Blikra G: Intradural herniated lumbar disc. J Neurosurg 31: 676-679, 1969

3. D'Andrea G, Trillo G, Roperto R Celli P, Orlando ER, Ferrante $\mathrm{L}$ : Intradural disc herniations: The role of MRI in preoperative diagnosis and review of the literature. Neurosurgical Review 27:75-80, 2004

4. Epstein NE, Syrquin MS, Epstein JA, Decker RE: Intradural disc herniations in the cervical, thoracic, and lumbar spine. J Spinal Disord: 4396-403, 1990.

5. Hodge CJ, Binet E, Kieffer S: Intradural herniation of lumbar intervertebral discs. Spine 3: 346-350, 1978

6. Jenkins LE, Bowman M, Colter HB, Gildenberg PL: Intradural herniation of a lumbar intervertebral disc. J Spinal Disord 2(3):2196-200, 1989

7. Koç RK, Akdemir H, Oktem IS, Menku A: Intradural lumbar disc herniation: Report of two cases. Neurosurg Rev 24:44-47, 2001

8. Mut M, Berker M, Palaoglu S: Intradural disc herniations in the lumbar spine and a new classification of intradural disc herniations Spinal Cord 39:545-548, 2001

9. Sengoz A, Kotil K, Tasdemiroglu E: Posterior epidural migration of herniated lumbar disc fragment. J Neurosurg Spine. 2011 Mar;14(3):313-317. Epub 2011 Jan 21

10. Osdemir N, Yilmaz H., Acar UD, Tektas S: Intraradicular lumbar disc herniation: Report of two cases and review of the literature. Br J Neurosurg 18:637-643, 2004

11. Sarliève $P$, Delabrousse $E$, Clair $C$, Hussein $H H$, Schmitt $C$, Kastler B: Intradural disc herniation migration of an excluded fragment. Journal Clinical Imaging 28:170-72, 2004

12. Snow R.D, Williams J.P, Weber E.D, Richardson PH : Enhancing transdural lumbar disc herniation. Clin Imag 19: 12-16, 1995

13. Suzer T, Tahta K, Coskun E: Intraradicular lumbar disc herniation: Case report and review of the literature. Neurosurgery 43:400, 1998.

14. Whittaker C, Bernhardt M: Magnetic resonance imaging shows gadolinium enhancement of intradural disc. Spine 19: 1505-1507, 1994 